\title{
Learning to be a good husband : competing masculine identities in the Roman du Comte d'Artois
}

Rosalind Brown-Grant

\section{OpenEdition}

Édition électronique

URL : https://journals.openedition.org/crm/62

DOI : $10.4000 / \mathrm{crm} .62$

ISSN : 1955-2424

Éditeur

Honoré Champion

Édition imprimée

Date de publication : 10 décembre 2002

ISSN : 1272-9752

Référence électronique

Rosalind Brown-Grant, « Learning to be a good husband : competing masculine identities in the Roman du Comte d'Artois », Cahiers de recherches médiévales [En ligne], 9 | 2002, mis en ligne le 23 mars 2006, consulté le 15 décembre 2022. URL : http://journals.openedition.org/crm/62 ; DOI : https://doi.org/ $10.4000 / \mathrm{crm} .62$

Ce document a été généré automatiquement le 15 décembre 2022.

Tous droits réservés 


\title{
Learning to be a good husband : competing masculine identities in the Roman du Comte d'Artois
}

\author{
Rosalind Brown-Grant
}

1 For modern critics, medieval romance was an important literary vehicle for the dissemination of contemporary gender ideologies. However, whilst studies of the construction of feminine identities in romance have proliferated in recent years ${ }^{1}$, less attention has been paid to medieval views of masculinity ${ }^{2}$. In particular, there is one masculine role which remains largely unexplored in recent discussions of romance, even though it was crucial for the functioning of medieval gender ideology : that of the husband. Most studies of chivalric masculinity in romance have tended to focus on the male hero in terms of the contradictory demands of his public role as a knight and his private self as a lover. Even those critics who have examined how the knight's excessive uxoriousness complicates this dilemma (as in Chrétien de Troyes' Erec et Enide and Yvain), rarely deal with the specificity of what it means to be a husband in medieval romance in terms of the male hero's expected duties within that social and sexual role.

2 At first sight, this lack of critical attention to the question of husbandly identity may seem self-explanatory in the sense that the husband himself appears to be a fairly marginal figure in romance. Indeed, the dominant romance paradigm since the inception of the genre has been what we might term one of «innamoramento ». In this model, a young knight embarks on a quest through which his identity will be formed, falls for a young, unmarried woman and undergoes a series of trials in the course of which he proves both his military prowess and his love for her, a classic example being the first part of Chrétien's Cligés ${ }^{3}$. The ubiquity of this paradigm is perhaps due to the fact that the dynamic of the romance narrative assumes a hero who is free to pursue a quest which will lead to a satisfactory dénouement both for him as an individual and for the society on whose part he undergoes his ordeals. In gender terms, this narrative model lends itself perfectly to the affirmation of heterosexuality as a compulsory state ${ }^{4}$, in that the «natural» conclusion of both the hero's quest and the narrative itself is his 
marriage to his lady. Though the knight thus ends up becoming a husband, this is not a role which is explored in any detail in the narrative.

Even in romances of adultery, such as the Tristan legend or the tale of the Châtelain de Coucy, the husband-figure stays firmly marginalised. Rarely is he the hero of the text, since here the narrative is focalised through the adulterous wife and her lover ${ }^{5}$. In narratological terms, the husband is just another obstacle in the lover's pursuit of sexual pleasure with his married paramour, and so is frequently depicted as an unsympathetic character in order to preclude the reader's identification with him. A well-known example is Alis, the husband in the second part of Cligés, Chrétien's reworking of the Tristan narrative, a supremely foolish figure who is drugged by his wife into thinking that he is having sex with her, when in fact her body remains reserved for her lover.

Yet, this marginalisation of the husband-figure which arises from the modern scholarly preoccupation with reading the romances of the twelfth and thirteenth centuries can be challenged if we turn our attention to the largely neglected corpus of fourteenthand fifteenth-century works in the genre ${ }^{6}$. These late medieval romances, which have barely been touched on by those scholars interested in medieval notions of gender ${ }^{7}$, not only explore many of the issues concerning masculinity and femininity developed in the earlier romances but also open up new areas of enquiry. In particular, they offer an invaluable opportunity for examining the representation of husbands in late medieval culture.

of course, the paradigm of «innamoramento» remained very popular in the later romances, whether in original texts such as the mid-fifteenth-century Pierre de Provence or Cleriadus et Meliadice, or in the numerous late medieval mises en prose of twelfth- and thirteenth-century works such as the romances of Blancandin and Cleomadés. However, in addition to this familiar scenario, a number of romances of this later period examine a new theme : how a knight learns to put his social duty as husband before his selfish desires as an individual. They thus constitute what might be termed "romances of maturation" in which the knight's ultimate attainment of marriage is depicted as problematic rather than automatic. In such cases, the hero often has to renounce an early, unsuitable relationship and accept marriage to someone else whose worth as a spouse is validated by the hero's family and peer group. Thus, in Gilles de Chin, the hero has to learn to give up his first love in favour of a bride chosen by his kin whilst in the Burgundian reworking of Florimont, the eponymous knight has to abandon his passionate but unsustainable affair with a powerful fairy woman and instead marry a royal heiress.

6 This emphasis on the obligations of marriage can also be seen even in those late medieval romances which portray the hero's love for a married woman. Thus, in both Charles de Hongrie and Jehan d'Avennes, not only is adultery replaced by chastity on the part of the lovers, but the husband himself, rather than being depicted simply as an awkward and unsympathetic obstacle to the hero's desires, is presented as having legitimate rights over his wife, rights which the lover has to respect. Indeed, such narratives are careful to show how it is only on the death of the husband that the lovers can finally consummate their desire for each other and the hero take his rightful place as possessor of his lady within marriage. Here, rather than constructing himself in active opposition to the role of husband, as in the Tristan or Châtelain de Coucy paradigms, the lover himself aspires to gain the social and sexual status of a husband. 
7 One further group of late medieval romances is significant for the way in which they undertake a detailed examination of what it meant to be a married man. These texts, many of which were produced either for the Burgundian duke Philippe le Bon or for members of his immediate aristocratic entourage, are distinctive in taking marriage as the starting-point rather than the end-point of their narrative. Featuring a hero who is at once both knight and husband from the start, they address key issues such as bigamy (Gillion de Trazegnies), estrangement and repudiation of a wife (Histoire des Seigneurs de Gavre), and adultery, where the would-be adulterer, most unusually, is the husband himself (Roman du Comte d'Artois). Within this group, the Comte d'Artois is a particularly illuminating case-study of how, in their attempts to prescribe the " correct » mode of husbandly behaviour for their aristocratic readers, such works were permeated by elements of gender ideology from fields as diverse as medicine, canon law and marriage sermons ${ }^{8}$.

Written in prose and drawing on both folkloric and literary sources, the Comte d'Artois was composed by an anonymous author c. 1450-60. That it enjoyed a certain degree of success in its own time is suggested by the fact that it is preserved in three extant manuscripts, one of which was inventoried in Philippe le Bon's library at the time of his death in $1467^{10}$. Yet, modern critics have generally paid little attention to this text, tending simply to discuss it as one of the numerous Burgundian historico-realist romances which fuelled Philippe's propaganda efforts to enhance the prestige of those territories, such as Artois, which had recently come under his control ${ }^{11}$. Indeed, its modern editor, Jean-Charles Seigneuret, has even suggested that the work was designed to draw a flattering parallel between its hero, Philippe, Comte d'Artois, and his namesake, the Burgundian duke, in terms of their chivalric and amorous exploits ${ }^{12}$. However, when viewed from a gender perspective, a very different reading of the romance emerges. As we shall see, the Comte d'Artois is principally concerned with conducting a thorough examination of male marital conduct, one which it carries out by use of both verbal and dramatic irony and by playing knowingly on many of the generic conventions of romance.

9 The text recounts how a loving and loyal wife reclaims her wayward husband, the eponymous Comte d'Artois, who abandons her for the pursuit of chivalric prowess when they appear unable to have children. On his departure, he declares that he will return to her only if she fulfils three seemingly impossible tasks: getting herself pregnant by him, taking his favourite horse and obtaining his finest diamond; all without his realising it. In order to carry out this quest and win back her husband, the wife cross-dresses as a man and insinuates her way into his entourage at the court of the King of Castille where he has taken up residence as the king's champion against the Saracens. Then, temporarily discarding her male disguise, she short-circuits his desired adulterous liaison with the King's daughter (who is in fact ignorant of his amorous intentions) by substituting herself in his arms for the young woman and conceiving his child. Once she has also been granted the horse and diamond as gifts from her unwitting spouse, the victorious wife returns home and sends ambassadors to her husband representing all three estates of her subjects to persuade him to take up his rightful place once more as lord of Artois. Chastened by his experience, but delighted at the prospect of finally having a legitimate heir, the husband is reunited with his wife.

Even from the above summary, it is hard to agree with Seigneuret's assessment of the romance as simply a light-hearted piece of flattery of the man who was perhaps its 
implied addressee. That the text has a more didactic import is signalled in the divergence which it sets up between its opening and closing passages ${ }^{13}$. At the start, the prologue creates the expectation that the reader will be entertained by an account of a valiant knight's deeds: «[les] haultez entreprisez, amours et beaulx fais d'armez d'un conte d'Artois» (p. 1, lines 16-17). Yet, the final pages offer the reader a form of «doulce correction» (p. 153, line 335), by depicting the shamefaced hero returning home to his wife after having learnt an important lesson about his marital responsibilities. Summing up the central moral message of the text, the hero himself observes that: «l'omme qui est marié ne puet bonnement ne lecitement laissier sa femme sans grant essoine qui nulle rigle ne observe, tant pour luy tenir compaignie et payer le droit de mariage comme pour garder son peuple en justice et nourir en union " (p. 149, lines 192-6).

11 Thus, far from being a straightforward celebration of a chivalric hero, this romance appears to be a critique of the chief protagonist's behaviour in his role as husband, an impression which is confirmed if we read the text in the light of contemporary ideas on marriage. Georges Duby's famous discussion of two models of marriage in the Middle Ages is particularly useful for our purposes ${ }^{14}$. Duby argues that the early medieval nobility adhered to an "aristocratic» model of marriage. This model was essentially endogamic in being based on the exchange of women between closely connected families and the necessity of ensuring legitimate succession between the generations in order to maintain the coherence of dynastic territories. Given the primacy attached to succession in this model, a woman's failure to produce heirs could leave her in a vulnerable position as noble husbands frequently resorted to repudiation in order to take a second wife in the hope that she would prove to be more fertile than the first. In terms of the three goods of marriage, first conceptualised by St Augustine ${ }^{15}$, - offspring (proles), fidelity (fides) and the sacramental or indissoluble bond between the spouses (sacramentum) -, the aristocratic model in effect privileged the first of these over the other two. By contrast, the « ecclesiastical » model of marriage actively promulgated by medieval churchmen from the end of the eleventh century onwards, was exogamic in forbidding marriage between men and women related to each other within seven degrees of consanguinity or if they were linked by bonds of affinity such as godparenthood. Moreover, this model stressed the indissolubility of the marital union once it had been celebrated in accordance with canon law, that is, if consent had been clearly given on both sides and consummation had duly taken place ${ }^{16}$. For medieval churchmen, divorce was then only permissible in the case of adultery or incest. In rejecting childlessness as legitimate grounds for repudiation, the church thus privileged fidelity and particularly the sacramental bond over offspring as the chief goods of marriage. The model promoted by the Church eventually prevailed, although theologians were forced into a compromise with the aristocracy as noble husbands were able to turn the strict rule on consanguinity to their advantage, by citing incest as the grounds on which they wished to abandon an infertile spouse to whom they belatedly «discovered» they were related within the forbidden number of degrees. After the Fourth Lateran Council of 1215, the Church closed this loophole by relaxing the rule to only four degrees of consanguinity, and reserved to itself the exclusive right to rule on the marital practices of the aristocracy through the granting of dispensations ${ }^{17}$. 
12 From the twelfth century onwards, the Church's teachings on marriage and the spouses' roles within it were disseminated to the laity by preachers such as Jacques de Vitry and Guilbert de Tournai ${ }^{18}$, who enjoined their congregations to observe :

the essential goodness of marriage [...] the faith binding husband and wife to each other, the begetting of children, the sacramental character of marriage, and its function as a remedy for incontinence; the consequent duty of each partner to agree to have intercourse at the other's request ; [...] the obligation of the husband to treat his wife with respect, as his " socia ", and of the wife to obey her husband; the responsibility of parents for the moral education of children; [and] the duty to get married in public, not clandestinely ${ }^{19}$.

What such preachers stressed was the importance of fidelity and the sacramental bond in their presentation of marriage as a companionate and indissoluble union, within which each was the other's helpmeet. If the wife was deemed to be ultimately subject to her husband's rule, the husband was nonetheless meant to behave in a benevolent rather than despotic fashion towards his wife.

In the later Middle Ages, such views were promoted not only by churchmen such as Jean Gerson (1363-1429) in his marriage sermons and Jacques Legrand in his ad status collection, the Livre de bonnes meurs (1404-10), but also by pious noblemen such as Philippe de Mézières and lay figures such as the Ménagier de Paris in his conduct book for his young wife (c. 1393). Given the didactic culture shared by these writers, it is perhaps more accurate henceforth to describe this model of marriage as "clerkly" rather than strictly « ecclesiastical». On the question of the goods of marriage, Jacques Legrand acknowledged the importance which the laity attach to offspring as a product of wedlock when he stated that «Mariage est ordenéz pour lignee avoir et pour aimer l'un l'autre $»^{20}$. Yet he also emphasised the need for mutual love and particularly for sexual fidelity between spouses : « loiauté est donné a entendre que nulle des parties de mariage ne doit son corps en nulle maniere forfaire, ains se doit tenir a sa partie $»^{21}$. Likewise, Jean Gerson saw offspring less as a defining feature of a wedded union and more as one of the few legitimate reasons for sexual intercourse between married partners ${ }^{22}$. Instead, he privileged the sacramental bond and the "loyaulte amoureuse " of the wedded couple to each other as the chief goods of marriage ${ }^{23}$, although he also stressed that this marital love itself should be a moderate emotion not to be confused with the extreme but ephemeral passion of «amer par amours ». For Gerson, love based on passion was no foundation on which to build an harmonious marriage ; as he put it: "plaisance luxurieuse tantost passe, riote demeure $»^{24}$. Philippe de Mézières echoed these views in his Livre de la vertu du sacrement de mariage (1384-9) when he insisted that the true significance of marriage lies in the spiritual bond between husband and wife rather than in the physical bond of "copulation charnele $»^{25}$. He was therefore forthright in his condemnation of the "aristocratic » practice of husbands who exploit the consanguinity rule in order to rid themselves of infertile wives ${ }^{26}$. Even when addressing Charles VI himself in his Songe du vieil pelerin (c. 1389), he expressed his hope that the king and queen would be blessed with children but added that, if this was not the case, the queen nonetheless still had a crucial maternal role to play in the spiritual domain as «mere de tous les pauvres du royaume et de tous ceulx qui seront en affliction et en amere tribulacion ${ }^{27}$. In terms of the specific role of the husband in this "clerkly» model of marriage, Gerson's promotion of St Joseph as a marital exemplar was to prove particularly influential as the cult of this saint took off in the course of the 
fifteenth century ${ }^{28}$. Rejecting the iconographical tradition of depicting Joseph as a decrepit, impotent and even foolish figure, Gerson maintained that Mary's husband displayed great vigour in his role of "chief et seigneur» of the Holy Family ${ }^{29}$. He presented Joseph as commendably industrious in looking after his wife and son's material needs, as loving and caring in his affectionate attentions to them, and as strong and authoritative in protecting his family when faced with danger ${ }^{30}$.

If such was the theory concerning marriage, what influence did the Church actually have on the marital practices of the late medieval nobility? C. A. J. Armstrong's analysis of Burgundian matrimonial policy in the fifteenth century ${ }^{31}$, reveals that the dukes adhered to the "aristocratic» model of marriage to the extent that they tended to marry women to whom they were closely related, since many of them were connected to the royal house of Valois. For example, Philippe le Bon's first wife, Michelle de France (m. 1409), was the daughter of King Charles VI, Philippe's great uncle, whilst his second wife Bonne d'Artois (m. 1424), was his aunt by marriage. Yet, in order to further their dynastic aims, the dukes were obliged to accommodate the "clerkly» model of marriage by seeking papal dispensations before the proposed unions could be celebrated. Ironically though, these endogamic marriages, which had been contracted for the specific purpose of safeguarding succession, actually produced few male heirs who lived to inherit their fathers' lands and title. Philippe, for instance, in the course of three marriages (as a result of the deaths of his first two, infertile spouses) managed to sire only one son who survived to maturity ${ }^{32}$. However, if the Burgundian dukes subjected themselves to the Church's authority in seeking its permission to marry their spouse of choice and in remaining married even if their wives proved infertile, they were no great observers of clerical teachings on fidelity as one of the chief goods of marriage. Philippe, like many of the noblemen who frequented his court ${ }^{33}$, conducted numerous extra-marital affairs in the course of which he proved himself to be a prolific progenitor of illegitimate children.

It is thus within the context of an aristocratic culture intensely preoccupied with dynastic matchmaking and the provision of legitimate heirs, yet cavalier in its attitude towards male infidelity, that the Comte d'Artois was written. Offering an oblique commentary on the marital inconsistencies of the Burgundian nobility, it endorses and propounds a more orthodox view of suitable husbandly behaviour, one which echoes many of the precepts put forward by figures such as Gerson and Legrand. As we shall see, rather than just fulfilling his role of husband in "aristocratic » terms by producing an heir to inherit his title and lands, the hero Philippe has to learn to conform to the «clerkly» model of the husband who is bound to his wife by a solemn sacrament based on love and faith. The text thus takes the motif of childlessness, a common theme in romance texts, ${ }^{34}$ and uses it for a particular moral purpose, that of showing how it leads to a crisis of masculine identity in the hero, one which can only be resolved when he has learnt to live « en joye amoureuse » (p. 153, line 318) with his wife, according to the tenets of a companionate marriage.

The opening chapters of the romance portray the hero as he is about to abandon what we may usefully term the "singleman " role of the young, unattached knight who is free to pursue renown and pleasure, in order to take up the husbandly role of the mature man who has duties to both his spouse and subjects. At first sight, Philippe appears to be a perfect candidate for this new role, being a paragon of all the military and amorous virtues. He is thus depicted as a supremely gifted warrior who 
accomplishes extraordinary acts of valour in order to save the honour of French knighthood against the English and the Germans in the tournament at Boulogne. Since this tournament is a thinly-disguised competition for the hand of the daughter of the Count of Boulogne, the hero also reveals himself to be a highly desirable match. Arrayed in striking red armour, which here probably signifies his valour and courage ${ }^{35}$, with his «lance sur la cuisse» (p.10, lines 49-50), Philippe cuts a virile figure which doesn't fail to impress the ladies of the court (p. 11). At the dance before the tournament, he and the Count's daughter fall for each other immediately, which thus pre-empts any extended lovesickness or anguish on the hero's part. Philippe's amatory success then inspires him to win the tournament and to ask her father to accept his suit, at which point the wedding is duly celebrated.

Yet, even on his wedding day, the hero's actions hint at an immaturity which means that he will prove unable to perform this new role successfully. Rather than excusing himself from jousting at the tournament held to celebrate his marriage, Philippe insists on competing in the lists. In so doing, he acts contrary to a convention of many romance texts, namely that the bridegroom should not risk seriously injuring himself before his wedding night ${ }^{36}$. That his behaviour is inappropriate is suggested within the narrative in a number of ways. For example, his bride herself betrays a certain ambivalence about her husband's choosing to joust at the wedding since she fails to respond overtly to the praise of him by others : « combien que la belle n'en deist mot ne bien ne mal, sy ooit elle loër ce que plus amoit, desiroit et volentiers veoit » (p. 21, lines 103-5). That his passion for jousting is excessive is signalled by the fact that onlookers at the tournament, delighted by his skilful performance, nonetheless comment on his extraordinary attachment to deeds of arms which they describe using a string of nearsynonyms as : «son deduit, sa nourreture et son joieulx passetempz » (p. 20, lines 88-9). Moreover, the colour blue of his shield, "l'escu d'azur» (p. 20, line 79), a colour commonly associated with fidelity in courtly literature from Froissart onwards ${ }^{37}$, turns out to be misplaced. Rather than remaining faithful to his wife, the hero soon directs his thoughts towards a different woman, eventually even forgetting that he is married: «[le] penser amoureux de la belle fille du roy [...] luy faisoit entr'oublier pays, femme et toutez aultrez chosez mondainez » (p. 98, lines 300-2).

19 On failing to impregnate his wife on his wedding night, contrary to the usual romance convention of almost instantaneous conception of a male heir ${ }^{38}$, and on seeing this situation unchanged after the first two or three years of marriage, Philippe begins to call his identity into question. No longer a singleman defined in terms of his military and amorous prowess, neither is he a husband defined in terms of his generative prowess. The hero thus comes to interpret his marriage according to the "aristocratic " model whereby his husbandly role is primarily to ensure succession, a role based on his sexual potency, rather than according to the «clerkly » model that would require him to fulfil the role of companion to his wife, as he had done in the early years of their marriage which they had spent «joieusement» together (p. 22, line 152). In theological terms, the hero overvalues offspring as the chief good of marriage at the expense of the goods of the sacramental bond and fidelity, and it is this failure to produce children which causes him to leave his wife without seeking her consent and so to cease paying the conjugal debt. The narrator underlines the illegitimate nature of Philippe's actions by showing how they are at total variance with a marriage that has been properly sanctioned in accordance with canon law. Thus, their union was initially based on 
mutual affection, since both were said to be smitten by the same "sayette d'amours " (p. 6, line 141), there was clear consent on both sides (p. 16, line 82) and consummation took place immediately, as bride and groom are described as enjoying a «double plaisance» (p. 22, line 138) on their wedding night. Yet, unable to complete the transition from unattached knight to « aristocratic » husband, Philippe's response is to shed his husbandly identity altogether and to reinvent himself as a singleman, thereby violating his marriage vows.

Through the use of multiple ironies, the narrator exposes the transgressive and doomed nature of Philippe's attempt to reassert himself as an unmarried knight and lover. The hero's desire to re-construct his identity in terms of his military prowess leads him to undertake a series of exploits which are typical of the singleman in romance narratives. On one level, he gives a very convincing performance of this masculine role: he offers a dazzling display of feats of arms in tournaments in Paris ( $p$. 26 ); helps lift the siege of an unjustly attacked nobleman, the Comte d'Urgel (pp. $29-46)$; acts as champion in a judicial duel to defend the honour of a calumniated maiden, the Comtesse de Cardonne (pp. 51-59); and fights as a valiant defender of the faith against the Saracens on behalf of the King of Castille (pp. 67-96). He proves himself to be not only a supremely brave warrior (against the Prince de Catalogne, Urgel's enemy) and a clever tactician (in his ambush of the Saracens), but also an inspiring and eloquent rallier of men (against the Saracens and Catalans) and a merciful victor towards his defeated enemies (such as the maiden's calumniator, the seigneur de Moncalde). In all his relations with other men, whether his allies, patrons or companions in arms, the hero forms the appropriate chivalric bonds based on male solidarity ${ }^{39}$. For example, the narrator describes how the hero and the young Comtesse's uncle, the King of Aragon, «se conjoïssent par grant amistié » (p. 59, lines 199-200), and he is universally praised for the courteous and respectful way in which he treats his male peers.

However, on another level, the narrator subtly undermines the hero's chivalric performance. That his military zeal is excessive (as was his previous attachment to jousting), even bordering on the unnatural, is signalled by the frequent description of his deeds as «desmesuré » (p. 42, line 96) and of his fury in battle as being that of an "[homme] faez» (p. 43, line 100), a man under some kind of enchantment. This emphasis on Philippe's " démesure ", a pejorative term in medieval culture, contrasts with the more positive and unambiguous description in contemporary romances such as Jehan d'Avennes and Ponthus et Sidoine of the hero's ability to " faire merveilles » on the field. Once he starts performing not only for his own glory but in order to impress the King of Castille's daughter, by making sure that «il en fust parlé jusquez a sa dame, la fille du roy dont il estoit amoureux nouvellement » (p. 71, lines 144-5), these epithets come even thicker and faster. In depicting the hero as being « faé ou homme inmortel » (p. 76, line 162), and as fighting «desmesureement» (pp. 86-7, lines 98-9) and with « rage desmesuree» (p. 93, line 116), the narrator thus highlights both Philippe's overcompensatory desire to distinguish himself through feats of arms and his wrongful wish to gain the favour of a woman whom he has in fact no right to court.

At several points in the narrative, Philippe's illegitimate attempt to pass himself off as a singleman is exposed by the use of irony. Firstly, there is the divergence between the hero's theory of marriage and his own inability to put this theory into practice. Thus, 
Philippe is shown exhorting the vulnerable Comtesse de Cardonne to marry the Prince de Vienne, in order that she might "avecquez luy vivre amoureusement et a son prouffit » (p. 65, lines 35-6, emphasis added), when he himself has failed to do just this with his own wife. Instead, he has allowed his disappointment at their childlessness to make him turn away from her, causing her to regret his disregard for «le bon tempz que par l'espace de .ii. ou .iii. ans nous avons ensamble sy amoureusement mené » (p. 116, lines 120-2, emphasis added). Secondly, there is a telling lack of fit between, on the one hand, Philippe's chivalrous behaviour and language in his guise as singleman towards both his male peers and other ladies and, on the other hand, his dereliction of duty towards his wife. His desire to protect ladies such as the Comtesse de Cardonne, whose lands are in danger without a male to defend them, and the kindness of his speech towards them, his « doulcez et bellez devisez » (p. 62, lines 299-300), contrast markedly with his abrupt departure from Artois which left his wife and his own subjects without a protector, and with the "dur et divers langage » (p. 24, line 50) which he employed on saying goodbye to her. Through inconsistencies such as these, the hero's martial overachievement is ironically subverted by his marital under-achievement, thereby critically weakening his chivalric credibility.

The other side of his attempt to reinvent himself as a singleman, that is as a lover, also meets with only partial success. Philippe does perform the role of the amorous knight with a certain degree of conviction, since he manages to convert the melancholic symptoms which he suffers as a seemingly infertile husband into those of a lovesick soupirant. On the couple's failure to produce a child, Philippe succombs to a state of profound melancholy : «sy ne se pooit son cuer nullement oster de merancolie, pensant a quoy il tenoit que nulz enffans ne pooit avoir de sa femme; et tant y musa et pensa que tout en devint changié, pale et tout descoulouré » (p. 22, lines 158-61). Once he falls into this state, his childlessness becomes self-confirming, since, in medieval medical discourse, the melancholic man, due to his coldness and dryness, was thought the least likely either to be able to perform sexually or to produce sperm of the requisite quality for conception ${ }^{40}$. For instance, in Placidés et Timéo, the popular late thirteenth-century encyclopedia of natural philosophy, the author notes that women had best avoid melancholic men as : «Peu ont appetit et peu en peuent faire; pour ce qu'il sont frois, et perdent tout appetit; pour ce qu'il sont ses, peu en peuent $»^{41}$. In describing the hero's condition as melancholic, the narrator is perhaps hinting here that it is Philippe rather than his wife who is responsible for their continuing lack of children. Indeed, on his departure from her, the hero himself tries to reassure his wife that she is not at fault in any way: «je ne le fais pour mal ne desobeïssance que je sache en vostre personne» (p. 25, lines 78-9). Moreover, the fact that the impossible task he sets her, that of becoming pregnant by him without his knowing, also suggests that he thinks himself incapable of siring a child. However, when he meets the King of Castille's daughter, Philippe begins to reassert his sexual identity through his love for her and so shakes off the melancholic symptoms caused by his frustrated paternity: «car grant bien luy faisoit son gent regarder seulement; et, apprez disner, il ala lez damez convoyer et soy solacier en leurs chambres pour passer tempz et dechasser merancoliez » (p. 67, lines 18-21, emphasis added). Ironically, in attempting to construct himself as the girl's lover, Philippe actually falls prey to the same symptoms as before, losing strength, appetite, joy and colour (p. 112, lines 172-8). Yet, this time, his melancholic symptoms are due to a different condition - lovesickness ${ }^{42}$ - and are thus the 
masochistic, bittersweet sufferings of a conventional singleman rather than the humiliations of an infertile husband.

Despite this partial success at casting himself in the role of the lover, albeit one whose passion is as yet unrequited, Philippe's amorous aspirations are destined never to be fulfilled, as the narrator underlines by flouting two key conventions of romance. The first of these is the topos of the lover and the lady suffering the pains of love in parallel. At first sight, our hero appears to conform to the generic norm, familiar from Chrétien de Troyes and Marie de France onwards, of the lover who is indomitable in the field of battle but hopelessly tongue-tied in the field of love, as when the narrator states that « il estoit tant craintif d'oÿr le reffus de sa dame que pour ce n'eust osé sa bouche ouvrir pour requerir mercy » (p. 112, lines 169-70) ${ }^{43}$. Yet, in Cligés or Guigemar, what adds to the piquancy of the singleman hero's love pangs is the fact that his lady is in similar agonies to his, which if he only knew it would bring him great comfort. The ironic twist in the Comte d'Artois is that at no time does the King of Castille's daughter seem to be aware of the hero's feelings for her ("qui a son mesaise jamais n'eust pensé » (p. 121, line 45)), let alone to be pining for love of him! Far from being the sexually assertive female who flouts her parents' wishes in order to express her desires (as in Cleomadés or Pierre de Provence), the girl is attentive to him only within the bounds of courtly propriety. Her remoteness from her would-be lover is signalled by the fact that she is never depicted as an autonomous being to whose feelings the narrator gives us access, but rather only as a member of a larger family group that has welcomed the hero to their court: for example, «Le roy, sa femme et sa fille, avecques leur chevalerie, se party de Toulette et ala en la ville de Daldolif, ou voulentiers se tenoit [...] et fist logier le conte d'Artois tant bien c'onquez mieulx sceut» (p. 98, lines 288-92). Furthermore, the girl not only never speaks in direct discourse to the hero but is kept physically apart from him at key points in the narrative either by her governess who acts to protect her honour, or by Philippe's wife herself when she takes the princess's place in the assignation with her husband. The hero's love for someone who is totally unaware of his suffering thus only serves to highlight the irrational and doomed nature of his desires.

The second example of the narrator undermining Philippe's status as a lover comes in his subversive treatment of the topos of the lady as the «doctor » or «medicine » who can cure the hero's lovesickness. In accordance with this topos, first popularised in the Tristan legends ${ }^{44}$, Philippe deems his illness to be treatable only by possessing his desired lady, whom he refers to as his «medecine» (p. 112, line 172). Yet, in practice, it is his own wife, for whom he never felt such violent and debilitating emotions when he fell in love with her, who actually fulfills the role of doctor by curing him through a magisterial piece of trickery. In her guise as his valet, she detects and accurately interprets all his symptoms as those of lovesickness which everyone else around him has put down to exhaustion from battle. She overhears his laments and tears, as well as his blame of his eyes for first alighting on his lady and of his heart for idealising someone so elevated above him, and recognises that his amorous fixation is both irrational (a «folie», p. 116, line 126), and potentially fatal (ibid., line 117). Confronting the hero with her diagnosis, she declares: «vous dis je que tant me congnois en vostre maladie que certain suis qu'elle vous vient d'amours, comme assez l'ay entendu par lez regrez et plaintez [...], que vous avez fait par plusieurs nuis, tant piteusez que [...] n'est mie possible qu'en tel estat puissiez longuement vivre » (118, lines 173-9). In accepting 
his faithful valet's help, in the hope that "par vostre moyen je soye allegié de ma dolereuse maladye » (ibid., lines 198-9), Philippe unwittingly confirms his wife's role as his actual cure, for it is in tricking him into thinking he is sleeping with his paramour when he is actually making love to his own spouse - that she brings his suffering to an end. This psychological cure is none the less effective for being based on subterfuge, since Philippe exclaims to the woman in his arms : «Et bien me doy jugier eureulx et tout vostre serviteur, quant ceste courtoisie m'avez faitte que de moy guerir de ce dont nul aultre que vous ne me porroit guerir ne donner allegance» (p.133, lines 35-8, emphasis added). In a supreme piece of dramatic irony, the hero thus deems himself to be a satisfied singleman whose lovesickness has been cured by his lady when he is in fact being made to perform the role of a dutiful husband in bed with his wife. Moreover, unbeknownst to him, the illicit pleasure of adulterous intercourse has thereby been rechanneled into sex within marriage for the more orthodox purpose of procreation.

If, having been found wanting as a singleman, Philippe learns by the end of the narrative to accept his role of husband, it is his wife who, in performing to the letter her own role of good spouse, re-imposes this identity on him. Marriage, for the wife if not for her husband, is absolutely indispensable to the construction of her own identity. Throughout the story, unlike Philippe, who has a name and an existence prior to and outside marriage, his spouse is never named, being referred to solely in terms of her relationships with the men who confer her identity on her, first as daughter and then as wife. She is either the "fille du Comte de Boulogne" or the "Comtesse d'Artois ", this latter title having no meaning for her if the "Comte " himself is absent from her side, as she states that she would prefer to die rather than live without him "seule hanbandonnee sans donner esperance d'estre en sa gracieuse compaignie jamais!» (p. 100, lines 51-3). Even when she chooses a name for herself in her crossdressed disguise as her husband's valet, she calls herself by a diminutive form of his name, "Philipot ", as if highlighting the extent to which her identity is dependent on his and the indissolubility of the bond between them as spouses.

What, then, defines the Comtesse d'Artois as a worthy wife and how does her good example show her husband how he is expected to behave? As in its general conception of marriage, this romance is indebted for its view of the spouses' respective roles within wedlock to the "clerkly» model of marriage expounded in the writings of Legrand, Gerson, Philippe de Mézières and the Ménagier de Paris. Despite the stress put on the companionate aspect of marriage in this model, the roles of husband and wife prescribed in these texts were not, of course, identical since the two sexes did not share an equal balance of power within marriage, such that many of the gender asymmetries and double standards surrounding medieval notions of inferior femininity and superior masculinity ${ }^{45}$ remained firmly in place. Thus, if husbands are enjoined to offer their wives love and protection, - advice which, as we have seen, the hero of the Comte d'Artois fails signally to follow, - wives are urged to display discretion and obedience, attributes which underline their subjection to their husbands. Whilst Philippe de Mézières described the husband's role as being to provide "a sa femme doulce cohabitation, obseque et service en tous cas neccessaires $»^{46}$, Gerson exhorted wives to "dissimuler paciamment aucuns deffaulx des maris ${ }^{47}$ and Legrand stressed that wives should always feel «honte de mesprendre et paour de desobeÿr $»^{48}$. The importance of these two wifely virtues is similarly highlighted by the Ménagier de Paris who devoted two of the longest exempla in his text to the popular tales of Griseldis and Prudence, 
wife of Melibee, as the supreme incarnations of obedience and discretion, respectively ${ }^{49}$. Although the Ménagier acknowledged that the suffering which Griseldis underwent was unnecessarily excessive, he nonetheless reiterated the crucial need for obedience in wives ${ }^{50}$, and approved wholeheartedly of the discretion shown by the wise Prudence who dissuaded her husband Melibee from rushing to avenge a brutal attack on his household: "sagement, subtillement, cautement et doulcement doivent les bonnes dames conseiller et retraire leurs mariz des folyes et simplesses dont elles les voyent embrasez et entechez, et non mye cuidier les tourner par maistrise, par hault parler, par crier a leurs voisins ou par les rues, ou par les blasmer, par elles plaindre a leurs amis et parens, ne par autres voyes de mestrise $"^{51}$. For late medieval writers such as Gerson, Legrand, Philippe de Mézières and the Ménagier, it is in showing their love for their husbands through their discretion and obedience that virtuous wives prove themselves worthy of being loved in turn by their husbands. Though grounded on the unequal principle of wifely subjection, the «clerkly» model of companionate marriage which they espoused nonetheless enshrines a key notion of reciprocity through complementary marital roles.

By displaying the "correct» feminine virtues, the hero's wife in the Comte d'Artois shows total adherence to the duties prescribed for a wife and so, in turn, puts the onus on her wayward husband to fulfill his. The Comtesse is certainly highly discreet in acting so as to protect her husband's good name at all times. She not only uses the pretext of a pilgrimage to mask her own departure from her subjects (p. 103, line 141) and confides her secret only to the most trustworthy person she can find (the princess of Castille's governess), but she also discloses the truth behind her husband's absence to his subjects only once her mission has been accomplished (pp. 142-3) in order to persuade them to recall him to Artois (p. 147). Similarly, the Comtesse's obedience can be seen in the fact that she follows to the letter the terms of the "contract» that her husband sets her on his departure, even if this involves a clever piece of subterfuge on her part. Yet, her obedience also serves her own ends since it is by substituting herself for his lady-love in bed and by publicly showing his subjects how she has fulfilled the three conditions of his "estrange traittié " (p. 147, lines 108-9) that she re-constructs him as her husband. In so doing, she morally obliges Philippe to abide by the terms of his own contract, as he himself admits that «bien estoit accomply son veu et que par tant plus ne devoit selon raison differer a faire son desiré retour " (ibid., lines 126-8). If the ethical asymmetry of wives needing to exercise discretion and obedience in order to cover up their husbands' misdemeanours therefore remains unchallenged in this romance, the Comtesse's ingenuity in displaying these virtues nevertheless obliges the hero to adhere to his marriage vows by offering her once more the love and protection which, as her husband, it is his marital duty to render to her.

Yet, in addition to displaying these feminine attributes, the hero's wife also acts as a more direct moral exemplar for her husband by demonstrating those virtues which were deemed in clerkly discourses on marriage to be common to both sexes : affective loyalty and sexual fidelity. Both Legrand and Gerson declared «loyauté amoureuse » to be one of the cornerstones of wedlock, whilst Philippe de Mézières outlined the destructive nature of sexual infidelity, whether on the part of the husband or the wife: "Qui donques retrait et forfait l'office du sacrement de mariage l'un a l'autre il peche grandement et faulse son mariage et donne occasion de vraye dampnation $»^{52}$. In presenting the Comtesse as a model of both affective loyalty and sexual fidelity, the 
text appears to adhere to the theological notion popularised by churchmen such as Thomas of Chobham that wives could and should act as "preachers » to their wayward husbands, by using their feminine persuasive powers to encourage them to perform virtuous deeds ${ }^{53}$. Whilst the Comtesse never actually resorts to telling her husband what to do - her discretion is so absolute that she never even reproaches him to his face for his infidelity - her persuasively virtuous actions are shown to speak more loudly than any words she might have used.

Her unfailing loyalty to her husband is proved in the fact that, despite his betrayal of her, she, out of love for him, seeks to save him from death through an unrequited passion: "Certez voire folie est ce bien quant ainsy consumés vostre force et jonesse pour une dame qui par aventure ne tient compte de vous»(p. 116, lines 126-8). Moreover, loyalty is the key quality which others laud in her. The princess's governess, for example, explains to Philippe that «a la plus leal et meilleur dame, de quoy l'on puist tenir parolle, estez vous mariez et bien l'a monstré quant pour vostre amour a enduré tel paine » (p. 148, lines 150-3). Similarly, the Comte's own subjects sing his loyal wife's praises to him, citing this virtue as the chief reason for her successful completion of the quest which she attained "par son sens, subtillité et parfaitte lealté » (p. 147, lines 108-10).

If affective loyalty is presented in this text as a marital virtue which is meant to be upheld by both sexes, the importance of sexual fidelity on the part of the wife, and thus, by extension, on the part of her husband, is seen in the manner in which she undertakes her "queste amoureuse» (p. 102, line 120) to reclaim him. The narrator takes great care when presenting the Comtesse's cross-dressing to divest this device of any of the connotations of transgressiveness and sexual licence, whether hetero- or homosexual, which were frequently attached to it in medieval romance ${ }^{54}$. Instead, it is treated here merely as a means to an end, since it allows the wife to gain access to her husband without being recognised ${ }^{55}$. The wife chooses as her travelling companion an elderly servant, Olivier, to whose great age the narrator frequently alludes, describing him as « ung anchien gentilhomme » (p. 101, lines 88-9), and as «son viellaudin Olivier " (p. 103, line 160), in order to remove any hint of sexual impropriety in showing him travelling alone with his cross-dressed mistress. The only man on whom she does exert any kind of attraction in her guise as a male is, appropriately enough, her own husband, who declares his valet to be «le plus beau compaignon et honneste c'onquez mais saillist du paiis » (p. 108, lines 47-9) and «celuy que j'aime mieulx que nul homme de ce monde » (p. 139, line 36). Yet even this attraction is more of an indicator of the affection and esteem in which Philippe holds his manservant, the intimacy between them serving to show how the hero's skill at creating friendships with other males including his cross-dressed wife ! - is not matched by his ability to bond lovingly with his own spouse in her more normal guise. Unlike the eponymous heroine of the Roman de Silence or Marte in Ysaie le Triste who, in male dress, both attract the unwanted attentions of other women ${ }^{56}$, the disguised wife in the Comte d'Artois is presented as a courteous but sexually unavailable young man. Though «he» is seen by the ladies of the Castilian court as someone whose «fachon et belle maniere » are admirable (p. 120, line 25), this does not lead to any amorous involvement with them. Similarly, the valet/ wife's close friendship with the princess's governess is desexualised by being likened to that of two "seurs germaines " (p. 121, line 58) and she soon reveals the nature of her quest and thus her true sexual identity as a «belle et entiere femme » (p. 123, lines 22-3) 
in order to take the older woman into her confidence. The narrator thereby replaces any titillating hint of intimacy between two women, typical in romances of transvestism, with a non-sexual female solidarity. This motif of solidarity is more commonly found in «singlewoman» romances such as the Roman du Comte d'Anjou, in which a young girl escaping from unwanted male desires (often those of her own father) receives assistance and shelter from an older woman ${ }^{57}$. It is nonetheless aptly employed in the Comte d'Artois as a means of highlighting the wife's preservation of her chastity for her husband.

In her role as moral exemplar, Philippe's wife reminds her husband that the aim of sexual fidelity between spouses is to render to each other payment of the conjugal debt. By the end of the twelfth century, theological commentators were agreed that one of the key purposes of marriage was to provide an outlet for incontinence, and that it was the duty of the two spouses to help each other to avoid the sin of fornication ${ }^{58}$. This view was reiterated in the later Middle Ages in Gerson's definition of the «honnestete de mariage" as involving reciprocal payment of the conjugal debt «en compaignie charnelle selond ce que nature l'a ordonne pour avoir lignee $\aleph^{59}$. By substituting herself, a licit object of desire, for the illicit object of her husband's passions, the Comtesse succeeds in subverting her husband's would-be adulterous behaviour. She thus plays to perfection the prescribed marital role of saving her spouse from mortal sin, whilst simultaneously gaining satisfication of her own needs, according to "le droit de mariage» (p. 149, line 195).

However, even as the narrator underlines the need for sexual fidelity in both husband and wife, we can also find evidence of the moral double standard inherent in medieval gender ideology. As Philippe de Mézières points out, adultery, though reprehensible in either spouse, is particularly dangerous in wives as it leads to uncertainty about the true paternity of her offspring: "la femme fault assés pis que l'omme pour la generacion adultere qui aucunefois en est engendree, dont mainte noble lignie en est desheritee $»^{60}$. In emphasising the chastity of the Comtesse in her relations with all except her husband, the narrator not only constructs her as a moral exemplar of fidelity but also meets another crucial aim : that of ensuring the legitimacy of the child which she is carrying. To this end, the narrator stresses that there is no possibility of interpreting her pregnancy as being by anyone other than her husband. It is therefore significant that the only point in the text where a divine rather than human agency is said to be at work concerns the timing of the birth of the couple's child. This takes place exactly nine months after they first slept together in Castille, much to the husband's relief: "pour oster toutez souspechons ainsy que Dieux le vault, elle en delivra droit au bout de .ix. mois que son seigneur avoit geu avecq luy premierement, dont je ne vous sçavroie recorder les loëngez qu'il en fist a son Createur » (p. 153, lines 310-14). Thus, if the husband is chastised for his sexual infidelity by being forced to give up the girl he loves ( ala devers le roy dire le derrenier adieu et pareillement a la royne et a sa fille, a qui plus ne voulu penser ", p. 150, lines 211-13, emphasis added), he nonetheless receives the suitably "aristocratic» reward of a male heir. Although according to the "clerkly " model of marriage, the wife's role is not simply to produce a legitimate child but also to provide a loving corrective to her husband's wayward behaviour, her chastity and sexual fidelity are still presented in the narrative as being more important than those of her spouse. 

and deploying both theological discourses on the spiritual bond in marriage and medical discourses on the problems of procreation and passion, the Comte d'Artois teaches its noble audience how to choose between three competing models of masculinity. It rejects the "aristocratic» model of husbandly behaviour for being predicated on something so fundamentally precarious as male sexual potency which, if found wanting, can lead to husbands scapegoating and abandoning their wives. Instead the text advocates the model of the «clerkly » husband which, being based on the loving companionship and fidelity of both spouses, it portrays as ultimately more sustainable and viable. It also implicitly contrasts this legitimate form of husbandly identity with that of the singleman, rejecting the deleterious passions of lovesickness in favour of the more moderate but enduring emotions which are characteristic of companionate marriage.

In re-affirming the good of marriage as the basis of social order and of gender stability, the Comte d'Artois provides an important counterbalance to the common critical view that in romances it is female desires which are shown to be disruptive of society. This text reveals that male desires potentially have the same transgressive effect if not properly channelled through marriage, even though the social consequences for the transgressor may be less drastic in the case of men than of women. As a case-study of how the prescription of masculine roles in romance was not only influenced by contemporary discourses on love, sex, marriage and gender, but also sought to comment on the actual marital practices of the nobility ${ }^{61}$, the Comte d'Artois has a key part to play in challenging the traditional scholarly preoccupation with twelfth- and thirteenth-century romances. More research on this text and others of the later medieval period is essential if critics in the field are to gain a full understanding of how the construction of male and female roles in this genre evolved from the beginning to the end of the French Middle Ages ${ }^{62}$.

\section{NOTES}

1.See, for example, R. L. Krueger, Women Readers and the Ideology of Gender in Old French Verse romance, Cambridge, 1993. See also Krueger's contribution to her edited volume The Cambridge Companion to Medieval Romance, Cambridge, 2000, pp. 132-49, where she notes how « Many romancers portray women in a way that highlights their troublesome sexuality, their disruptive agency, or their resistant voices ». 2.One notable exception is S. Gaunt, Gender and Genre in Medieval French literature, Cambridge, 1995, pp. 71-121. For more general studies of masculinity in medieval culture, see C. A. Lees, ed., Medieval Masculinities: Regarding Men in the Middle Ages, Minneapolis, 1994 ; J. J. Cohen and B. Wheeler, ed., Becoming Male in the Middle Ages, New York, 1997 ; J. Murray, ed., Conflicted Identities and Multiple Masculinities: Men in the Medieval West, New York/London, 1999 ; and D. M. Hadley, Masculinity in Medieval Europe, London/New York, 1999. 
3.S. Kay, «Courts, clerks and courtly love», ed. Krueger, op.cit., pp. 81-96, 88-9.

4.Gaunt, op. cit.

5.P. McCracken, The Romance of Adultery: Queenship and Sexual Transgression in Old French Literature, Philadelphia, 1998.

6.For example, L. R. Muir, Literature and Society in Medieval France: The Mirror and the Image, 1100-1500, Basingstoke, 1985, and A. Berthelot, Histoire de la littérature française du Moyen Age, 1989, barely mention any romances after 1300, and even N. J. Lacy, «The evolution and legacy of French prose romance ", ed. Krueger, op. cit., pp. 167-82, gives the impression that the only late medieval romances worthy of study are Arthurian. However, for a more inclusive and wide-ranging view, see M. Zink, «Le roman », La Littérature française aux XIV et XV $V^{e}$ siècles, Grundriss der Romanischen Literaturen des Mittelalters, vol. VIII/1, Heidelberg, 1988, pp. 197-218.

7.One notable exception is M. Szkilnik. See, for example, her article « The grammar of the sexes in medieval French romance", Gender Transgressions: Crossing the Normative Barrier in Old French Literature, ed. K. J. Taylor, New York/London, 1998, pp. 61-88. 8.Le Roman du Comte d'Artois, ed. J.-C. Seigneuret, Geneva, 1966. All page references in the body of the text will be to this edition.

9.Seigneuret notes the similarity between the plot of this romance and Boccaccio's Decameron (III, 9) which would have been available in French translation to the anonymous prose author from 1414 onwards : see introduction, p. xxxii.

10.Ibid., p. xxi.

11.See, for example, Y. Lacaze, «Le rôle des traditions dans la genèse d'un sentiment national au XV $\mathrm{XV}^{\mathrm{e}}$ siècle. La Bourgogne de Philippe le Bon ", Bibliothèque de l'École des Chartes, CXXIX, 1971, pp. 303-85 ; and D. Quéruel, «Le Roman du Comte d'Artois : écriture romanesque et propagande politique ", Arras au Moyen Age : Histoire et Littérature, ed. M.M. Castellani and J.-P. Martin, Artois, 1994, pp. 137-49.

12.Introduction, pp. xxviii-xxix.

13.On the tension between entertainment and exemplarity in late romances, see $\mathrm{N}$. Cazauran, "Les romans de chevalerie : entre 'exemple' et 'récréation' ", Le Roman de Chevalerie au temps de la Renaissance, ed. M. T. Jones-Davies, Paris, 1987, pp. 29-48.

14.G. Duby, Medieval Marriage: Two Models from Twelfth-Century France, trans. E. Foster, Baltimore/London, 1978.

15.P. L. Reynolds, Marriage in the Western Church : The Christianization of Marriage during the Patristic and Early Medieval Periods, Leiden, 1994.

16.J. A. Brundage, Sex, Law and Marriage in the Middle Ages, Aldershot, 1993. See also P. Toxé, «La copula carnalis chez les canonistes médiévaux », Mariage et sexualité au Moyen Age: Accord ou crise? Colloque international de Conques, ed. M. Rouche, Paris, 2000,

pp. 123-33.

17.C. N. L. Brooke, The Medieval Idea of Marriage, Oxford, 1989 ; and N. Cartlidge, Medieval Marriage : Literary Approaches, 1100-1300, Cambridge, 1997.

18.D. L. d'Avray, Medieval Marriage Sermons : Mass Communication in a Culture without Print, Oxford, 2001.

19.D. L. d'Avray and M. Tausche, "Marriage sermons in ad status collections of the central Middle Ages ", Archives d'Histoire Doctrinale et Littéraire du Moyen Age, 47, 1980, pp. 71-119, 118. 
20.Jacques Legrand, Archiloge Sophie. Livre de bonnes meurs, ed. E. Beltran, Paris, 1986, p. 369. This text continued to be popular throughout the late Middle Ages : G.

Doutrepont, La Littérature française à la cour des Ducs de Bourgogne, Geneva, 1970, p. 231, notes the presence of a copy of the text in Philippe le Bon's library prior to 1467 . See also R. E. F. Straub, «Les manuscrits du Livre des bonnes meurs conservés à la Biblioteca Apostolica Vaticana ", "A l'heure encore de mon escrire ». Aspects de la littérature de Bourgogne sous Philippe le Bon et Charles le Téméraire, ed. Claude Thiry, special issue of Les Lettres Romanes, 1997, pp. 163-81.

21.Bonnes meurs, p. 370.

22.See D. C. Brown, Pastor and Laity in the Theology of Jean Gerson, Cambridge, 1987, pp. 236-7.

23. "De la chastete conjugale ", Jean Gerson: Oeuvres complètes, ed. P. Glorieux, 10 vols., Paris, 1960-73, vol. VII.1, pp. 859-68, 862.

24.Ibid., p. 860.

25.Philippe de Mézières, Le Livre de la vertu du sacrement de mariage, ed. J. B. Williamson, Washington, D.C., 1993, p. 221.

26.Ibid., p. 247.

27.Philippe de Mézières, Le Songe du vieil pelerin, ed. G. W. Coopland, 2 vols, Cambridge, 1969, vol. II, p. 350.

28. Brown, op. cit., p. 234.

29. CConsiderations sur St Joseph», ed. Glorieux, op. cit., vol. VII.1, pp. 63-98, 66.

30.D. Herlihy, Medieval Households, Cambridge, Mass., 1985, pp. 127-30. See also R. Drage Hale, "Joseph as mother : adaptation and appropriation in the construction of male virtue ", Medieval Mothering, ed. J. Carmi Parsons and B. Wheeler, New York, 1996, pp. 101-16.

31.C. A. J. Armstrong, «La politique matrimoniale des Ducs de Bourgogne », Annales de Bourgogne, 40, 1968, pp. 5-58, 89-139.

32.R. Vaughan, Philip the Good: The Apogee of Burgundy, London, 1970, pp. 132-5.

33.Ibid., p. 133.

34.See, for example, Gillion de Trazegnies, where childlessness is dealt with in terms of Christian stoicism, as the loving husband is saddened at his wife's failure to conceive but stresses that it is clearly God's will that they are childless, rather than any physiological defect in either of them ; and Robert le Diable, where the childless Duchess of Normandy resorts in desperation to praying to the devil for help in conceiving a son. 35.On the conventional symbolism of the colour red which could have these positive connotations or more pejorative ones of anger and pride, see M. Pastoureau, Figures et couleurs: Etudes sur la symbolique et la sensibilité médiévales, Paris, 1986, p. 40.

36.See, for example, Le Roman de Ponthus et Sidoine, ed. M.-C. de Crécy, Geneva, 1997, p. 178, lines 190-3, where the hero Ponthus shows his consideration for his wife and subjects in declaring that : «il ne seroit jamés d'assentement que l'en feist fait d'armes le jour des nopces, et dit ce pour le roy de Bourgongne qui estoit mort le jour de ses espousailles".

37.Pastoureau, op. cit., p. 17, cites Froissart's Dit dou bleu chevalier (1361-7) as instrumental in popularising blue as «la couleur de la loyauté et de l'amour fidèle». See also P. Ainsworth, "Heralds, heraldry and the colour blue in the Chronicles of Jean Froissart ", The Medieval Chronicle: Proceedings of the $1^{\text {st }}$ International Conference on the 
Medieval Chronicle, Driebergen/Utrecht 13-16 July 1996, ed. E. Kooper, Amsterdam/Atlanta, 1999, pp. 40-55.

38.For examples of narratives in which sons are conceived on the couple's wedding night, see Jehan de Paris, Olivier de Castille and Rambaux de Frise.

39.See M. J. Ailes, «The medieval male couple and the language of homosociality », ed. Hadley, op. cit., pp. 214-37.

40.V. L. Bullough, « On being a male in the Middle Ages », ed. Lees, op. cit., pp. 31-45, p. 41.

41.Placidés et Timéo ou Li secrés as philosophes, ed. C. Thomasset, Geneva/Paris, 1980, p. 211. See also C. Thomasset, Une vision du monde à la fin $d u X^{X I I}{ }^{e}$ siècle. Commentaire du dialogue de Placidés et Timéo, Geneva, 1982, pp. 111-63 ; and D. Jacquart and C. Thomasset, Sexualité et savoir médical au moyen âge, Paris, 1985.

42.See M. F. Wack, Lovesickness in the Middle Ages: The Viaticum and its Commentaries, Philadelphia, 1990 ; and Eros and Anteros: The Medical Traditions of Love in the Renaissance, ed. D. A. Beecher and M. Ciavolella, Toronto, 1992.

43.See J. Hall Martin, Love's Fools: Aucassin, Troilus, Calisto and the Parody of the Courtly Lover, London, 1972, p. 17.

44.See M. Ciavolella, La «Malattia d'amore » dall'Antichità al Medioevo, Rome, 1976 ; and Wack, op cit..

45.See V. L. Bullough, «Medieval medical and scientific views of women », Viator, 4, 1973, pp. 485-501 ; I. Maclean, The Renaissance Notion of Woman: A Study in the Fortunes of Scholasticism and Medical Science in European Intellectual Life, Cambridge, 1980 ; and J. Cadden, Meanings of Sex Difference in the Middle Ages: Medicine, Science, Culture, Cambridge, 1993.

46.Sacrement de mariage, p. 306, lines 2-3.

47. De la chastete», p. 862.

48.Bonnes meurs, p. 371.

49.Le Mesnagier de Paris, ed. G. E. Brereton and J. M. Ferrier, trans. Karin Ueltschi, Paris, 1994.

50.Ibid., p. 232.

51.Ibid., p. 400, lines 1459-65.

52.Sacrement de mariage, p. 306, lines 24-6.

53.See S. Farmer, «Clerical images of medieval wives », Speculum, 61,3, 1986, pp. 517-43. 54.See, for example, R. Davidson, "Cross-dressing in medieval romance », Textual Bodies: Changing Boundaries of Literary Representation, ed. L. Hope Lefkovitz, Albany, New York, 1997, pp. 59-74 ; and K. Busby, «'Plus acesmez qu'une popine' : male crossdressing in medieval French narrative ", ed. Taylor, op. cit., pp. 45-59.

55.Szkilnik, op. cit., p. 82.

56.Ibid., p. 65, 77.

57.A. Roberts, «Helpful widows, virgins in distress : women's friendship in French romance of the thirteenth and fourteenth centuries ", Constructions of Widowhood and Virginity in the Middle Ages, ed. C. L. Carlson and A. J. Weisl, New York, 1999, pp. 25-47 ; and Y. Foehr-Janssens, La Veuve en majesté: deuil et savoir au féminin dans la littérature médiévale, Geneva, 2000, p. 250.

58.See P. J. Payer, The Bridling of Desire: Views of Sex in the Later Middle Ages, Toronto, 1993 ; D. Elliott, Spiritual Marriage : Sexual Abstinence in Medieval Wedlock, Princeton, 1993 ; 
and J. W. Baldwin, The Language of Sex: Five Voices from Northern France around 1200, Chicago, 1994.

59.«De la chastete», pp. 860-1.

60.Sacrement de mariage, p. 306, lines 27-9.

61. Comparative analysis of fifteenth-century mises en prose of earlier romances with the original texts suggests a heightened preoccupation with marital roles in texts of the later period. For example, on the Burgundian reworking of Erec et Enide, see M. Wallen, "Significant variations in the Burgundian prose version of Erec et Enide ", Medium Aevum, 51, 1982, pp. 187-96 ; N. J. Lacy, " Motivation and method in the Burgundian Erec ", Conjunctures: Medieval Studies in Honor of Douglas Kelly, ed. K. Busby and N. J. Lacy, Amsterdam, 1994, pp. 271-80 ; and M. Colombo-Timelli, ed. L'Histoire d'Erec en prose, Geneva, 2000, introduction, p. 40.

62.I am grateful to the Arts and Humanities Research Board for funding the period of study leave in which this article was completed, and am indebted, as ever, to S. H. Rigby for his invaluable comments on my successive drafts.

\section{AUTEUR}

\section{ROSALIND BROWN-GRANT}

University of Leeds 